\title{
Characterizing groundwater and surface-water interaction using hydrograph-separation techniques and groundwater-level data throughout the Mississippi Delta, USA
}

\author{
Courtney D. Killian ${ }^{1,2}$ (D) - William H. Asquith ${ }^{3}$ - Jeannie R. B. Barlow ${ }^{1} \cdot$ Gardner C. Bent $^{4} \cdot$ Wade H. Kress $^{5}$. \\ Paul M. Barlow ${ }^{6}$. Darrel W. Schmitz ${ }^{2}$
}

Received: 2 April 2018 / Accepted: 26 April 2019 / Published online: 25 May 2019

(C) The Author(s) 2019

\begin{abstract}
The Mississippi Delta, a portion of the Mississippi Alluvial Plain (MAP) located in northwest Mississippi (USA), is an area dense with industrial-level agriculture sustained by groundwater-dependent irrigation supplied by the Mississippi River Valley alluvial aquifer. Observed declines in groundwater-level elevations and streamflow, contemporaneous with increases in irrigation, have raised concerns about future groundwater availability and the effects of groundwater withdrawals on streamflow. To quantify the impacts of groundwater withdrawals on streamflow and increase understanding of groundwater and surface-water interaction in the MAP, hydrograph-separation techniques were used to estimate baseflow and identify statistical streamflow trends. The analysis was conducted using the US Geological Survey Groundwater Toolbox open-source software and daily hydrologic data provided by a spatially distributed network of paired groundwater wells and streamgage sites. This study found that statistically significant reductions in stream baseflow occurred in areas with substantial groundwater-level declines. The use of hydrograph-separation and trend analyses to quantify the impacts of groundwater withdrawals and the use of streamflow as a proxy for changes in groundwater availability may be applicable in other altered environments. Characterizing and defining hydrologic relations between groundwater and surface water will help scientists and water-resource managers refine a regional groundwater-flow model that includes the Mississippi Delta, which will be used to aid water-resource managers in future decisions concerning the alluvial aquifer.
\end{abstract}

Keywords Groundwater/surface-water relations · Groundwater management · Baseflow · Alluvial aquifer · USA

Courtney D. Killian

ckillian@usgs.gov

1 US Geological Survey Lower Mississippi-Gulf Water Science Center, 308 Airport Rd. S, Jackson, MS 39208, USA

2 Department of Geoscience, Mississippi State University, 108 Hilbun Hall, Mississippi State, MS 39762, USA

3 US Geological Survey Texas Water Science Center, Science Building MS-1053, Texas Tech University, Lubbock, TX 79409, USA

4 US Geological Survey New England Water Science Center, Northborough, MA 01532, USA

5 US Geological Survey Lower Mississippi-Gulf Water Science Center, 640 Grassmere Park \#1000, Nashville, TN 37211, USA

6 US Geological Survey Earth Systems Modeling Branch, Northborough, MA 01532, USA

\section{Introduction}

Sustainable agriculture in the United States depends on appropriate management of groundwater resources. Water use in the United States in 2000 (the most recent year for which comprehensive groundwater withdrawal data have been published) was estimated at 1,544.4 billion liters per day (BL/ day) [408 billion gallons per day (Bgal/day)] and freshgroundwater withdrawals comprising about $315.3 \mathrm{BL} /$ day (83.3 Bgal/day), or approximately $20 \%$ of daily water use (Hutson et al. 2004). The majority of groundwater withdrawals were for thermoelectric power supply and irrigation (Hutson et al. 2004; Maupin and Barber 2005). An estimated $34.1 \mathrm{BL} /$ day of groundwater was withdrawn from the Mississippi River Valley alluvial aquifer (alluvial aquifer) alone in the year 2000 (Clark et al. 2011). The alluvial aquifer, 
located in the south-central United States, is the upper most aquifer underlying the Mississippi Alluvial Plain (MAP) and is the third largest provider of groundwater in the United States (Maupin and Barber 2005). The aquifer is approximately $76,400 \mathrm{~km}^{2}\left(\mathrm{~km}^{2}\right)\left[29,500 \mathrm{mile}^{2}\left(\mathrm{mi}^{2}\right)\right]$ and underlies portions of seven states-Arkansas, Illinois, Kentucky, Louisiana, Mississippi, Missouri, and Tennessee; Fig. 1a(Cushing et al. 1964; Hutson et al. 2004; Clark et al. 2011). Groundwater withdrawals from the alluvial aquifer in 2000 accounted for $10 \%$ of all estimated groundwater withdrawals (Fig. 1b) and $2 \%$ of all estimated water use in the continental United States (Fig. 1b; Hutson et al. 2004). According to local groundwater modeling studies (Telis 1991; Barlow and Clark 2011; Clark et al. 2011), the current rate of freshwater withdrawals is unsustainable.

The demand for groundwater resources from the alluvial aquifer for agricultural irrigation has resulted in substantial observed declines in groundwater-level elevation over time (Barlow and Clark 2011). Groundwater withdrawals have been cited as a driving factor of streamflow depletion, which has raised concerns for the future of available groundwater resources with local, state, and regional stakeholders (Theis 1940; Barlow and Clark 2011; Barlow and Leake 2012). The quantification of observed environmental changes in groundwater-level elevation and streamflow may be done using many available methods and software tools. Numerical groundwater models simulate groundwater flow and aquifer response to stresses such as groundwater withdrawals and can be useful to increase understanding of complex hydrologic systems (Clark and Hart 2009; Sahoo and Jha 2017). Numerical simulation is an oversimplification of realworld processes and many models fail to accurately represent the interaction of surface water and groundwater.
Fig. 1 a The Mississippi River Valley alluvial aquifer extent defined in the Mississippi Embayment Regional Aquifer Study (MERAS) model (Clark and Hart 2009; Clark et al. 2011). b Water use in 2000 for the continental United States and groundwater withdrawals for the alluvial aquifer

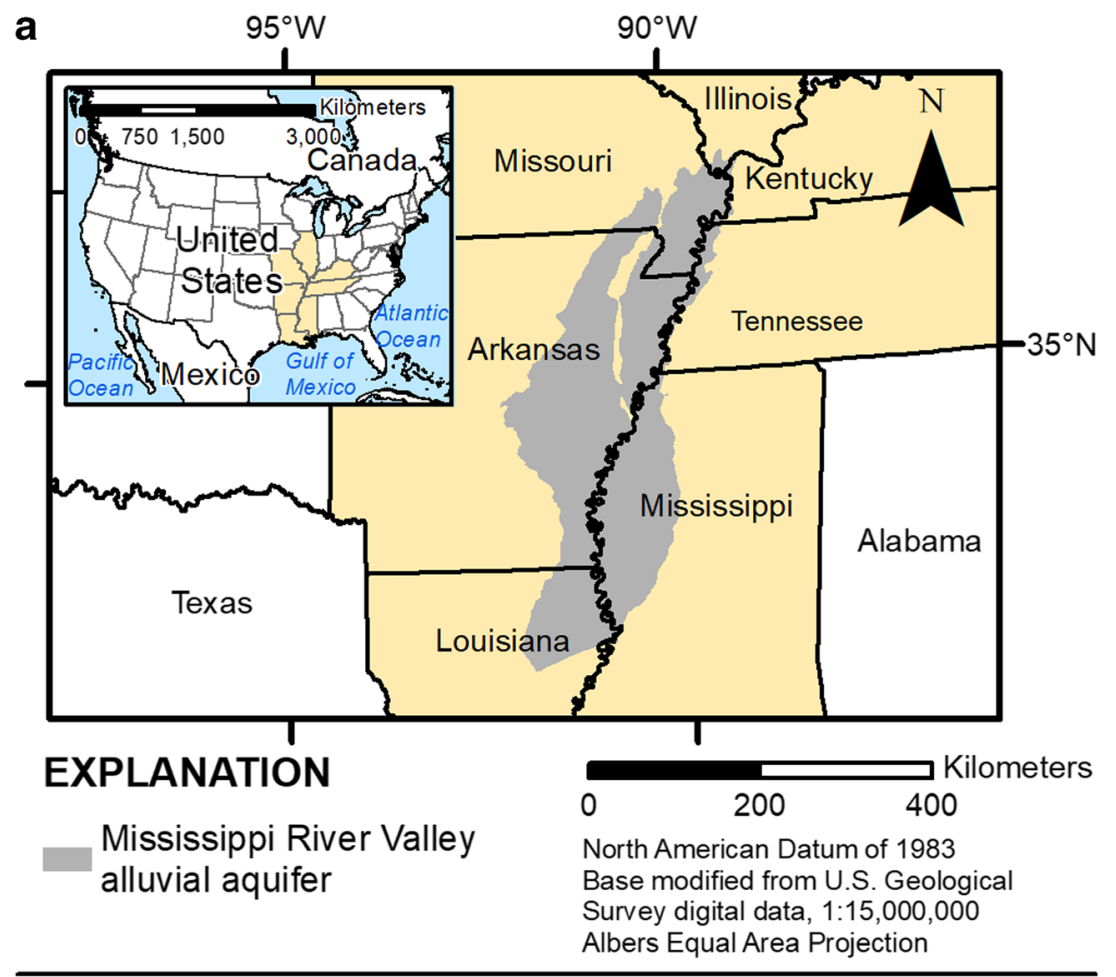

\section{b Water Use in the United States in 2000, billion liters per day}

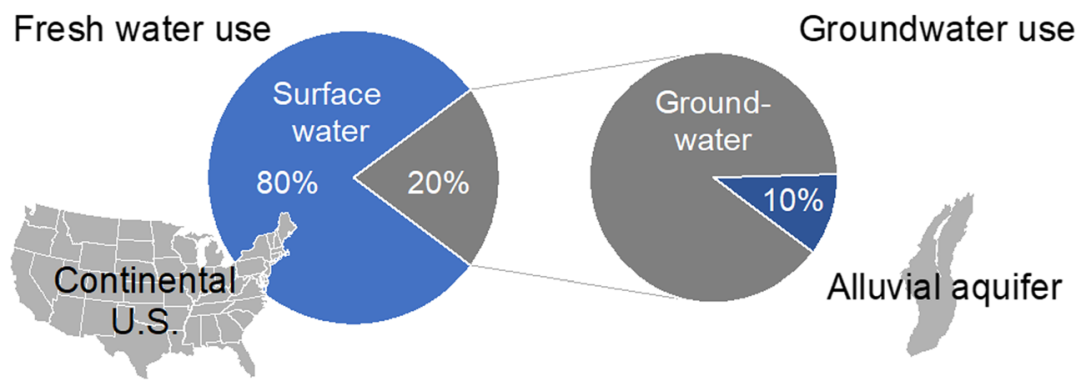


Numerical groundwater modeling may also be expensive in terms of time, money, and computational power. Although there are many examples in the literature of the use of numerical groundwater models to determine the impact of groundwater withdrawals on streamflow, there are comparatively fewer studies that have used statistical evaluations of streamflow and baseflow records to identify groundwater-withdrawal effects; the reader is referred to Wahl and Tortorelli (1997), Burt et al. (2002), McCallum et al. (2013), Abo and Merkel (2015), Juracek (2015), Miller et al. (2015), Juracek and Eng (2017) for examples of the latter. The current understanding of groundwater and surface-water interactions and associated water-resource management issues are documented (Winter 1995; Winter et al. 1998; Sophocleous 2002; Verry 2003; Brodie et al. 2007; Anibas et al. 2011; Barlow and Leake 2012; Barthel and Banzhaf 2015; Yang et al. 2017); however, the complexities of the interactions are not well understood, especially in systems with observed groundwater-level declines.

The purpose of this study was to quantify spatial and temporal trends in streamflow and baseflow at five sites in the Mississippi Delta using four hydrograph-separation methods to determine if observed streamflow and baseflow trends were statistically significant. A spatial correlation of changes in baseflow were compared to measured and modeled groundwater-level elevations as a possible indicator of groundwater-surface water interactions. Such an approach would provide a basic understanding of the impacts of groundwater withdrawals without or prior to the use of expensive numeric groundwater models. Results from the hydrograph-separation and trends analyses were compared to measured and modeled spatial and temporal groundwater-level elevations to identify if statistically significant temporal changes in baseflow occurred in areas with substantial declines in groundwater-level elevation. Quantification of observed declines in streamflow was conducted with the combined use of quantitative hydrograph separation and statistical trend analyses. This study aims to provide a computationally simple means for quantifying temporal changes in streamflow using existing streamflow data to detect potential changes in groundwater-level elevations that will help to improve the understanding of groundwater and surface-water interaction in alluvial settings, a topic of substantial interest by scientists (Theis 1940, 1941; Spalding and Khaleel 1991; Ackerman 1996; Renken 1998; Alley et al. 1999; Burt et al. 2002; Sophocleous 2002; Barlow and Leake 2012; Essaid and Caldwell 2017). Results of this study are anticipated to aid in the development of a decision support tool to help waterresource managers make informed decisions regarding water use.

\section{Study area}

This study focused on the Mississippi Delta (Fig. 1a), an area of dense agricultural activity in northwest Mississippi, with known water-level declines in the alluvial aquifer (Boswell et al. 1968; Pennington and Stiles 1994; Ackerman 1996; Renken 1998). The Mississippi Delta covers approximately $18,100 \mathrm{~km}^{2}\left(7,000 \mathrm{mi}^{2}\right)$ of north-west Mississippi and is an area with substantial industrial-scale agriculture that necessitates large volumes of fresh water for irrigation (Arthur 2001). About $98 \%$ of the fresh water used for irrigation is supplied by groundwater withdrawn from the alluvial aquifer (Arthur 2001; Barlow and Clark 2011). Groundwater withdrawals from the alluvial aquifer have been rising since the 1930s with a noticeable increase in the 1980s when a majority of agricultural producers switched from surface water to groundwater for irrigation following a drought (Fig. 2; Arthur 2001; Barlow and Clark 2011; Peterson et al. 2015). The alluvial aquifer is composed of Quaternary-age sands and gravel deposited after the Wisconsin glaciation, making it an ideal aquifer with well yields ranging from approximately 1,100 9,500 L/min (300-2,500 gal/min; Renken 1998; Arthur 2001; Yazoo Mississippi Delta Joint Water Management District, YMD) 2008).

Climate and precipitation are anticipated to have limited effects on groundwater-level elevations and streamflow in the Mississippi Delta. Groundwater-level elevation and streamflow declines are occurring despite an average increase in precipitation. From 1901 to 2017, the mean annual precipitation for the northern part of the Mississippi Delta was $132 \mathrm{~cm}$ [52 in. (in)] with an average increase of about

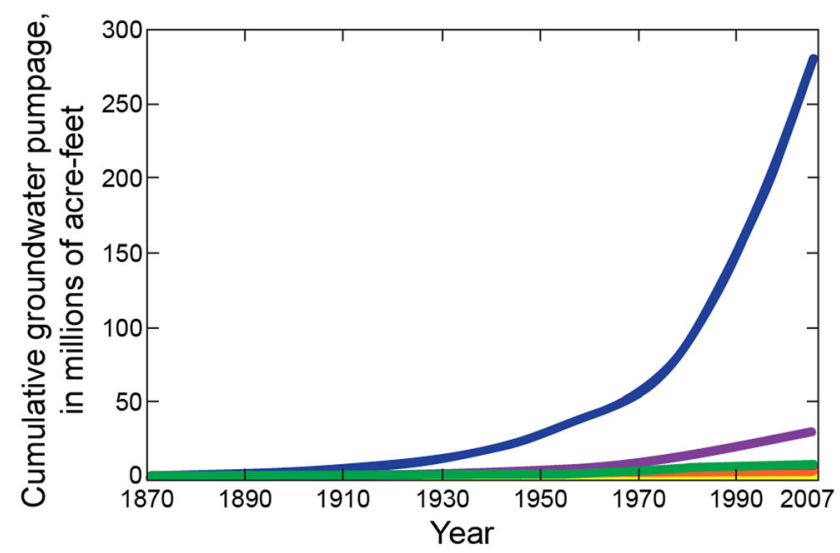

\section{EXPLANATION}

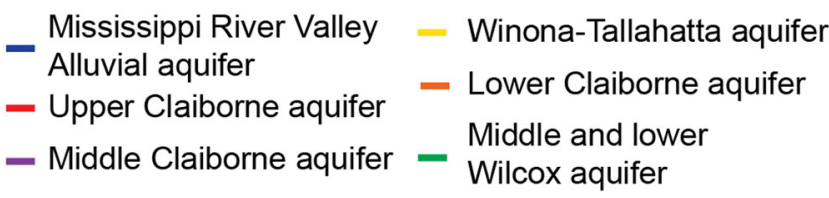

Fig. 2 Groundwater withdrawals from aquifers included in the Mississippi Embayment Regional Aquifer Study model; 1 acre-foot= $1,233.5 \mathrm{~m}^{3}$; modified from Clark et al. 2011 
$0.1 \mathrm{~cm}(0.03 \mathrm{in})$ per decade (National Oceanic and Atmospheric Administration, NOAA) 2018). The mean annual precipitation for the same time period for the southern part of the Mississippi Delta was $135 \mathrm{~cm}$ (53.0 in) with an average increase similar to that of the entire Delta (NOAA 2018). Much of the precipitation received in the MAP is lost to evapotranspiration (about 65\%) and runoff (about 29\%), leaving about $6 \%$ for recharge (Clark and Hart 2009; Kress et al. 2018). Areal recharge rates for the alluvial aquifer have been modeled in several studies (Ackerman 1996; Arthur 2001; Clark and Hart 2009), but few have attempted to calculate actual recharge rates until recently (Reitz et al. 2017; Kress et al. 2018). Most of the recharge to the Mississippi Delta portion of the alluvial aquifer is assumed to be lateral from the Mississippi River to the west and the Bluff Hills to the east (Arthur 2001). The population for the Mississippi Delta decreased by 1\% from 1960 to 2017 (Forstall 1995; US Bureau of the Census 2017). While the local population has declined, the global population is rising, and the Mississippi Delta supplies commodities used around the world. Between 1998 and 2007, approximately $1,412 \mathrm{~km}^{2}$ (349,100 acres) were added to the permitted area for water use in the Mississippi Delta (YMD 2008).

\section{Materials and methods}

\section{Quantitative hydrograph separation}

Hydrograph separation is a quantitative method to estimate baseflow contributions to streamflow by separating a timeseries of streamflow data into baseflow and surface runoff, the principal components of streamflow. The surface-runoff component of streamflow is assumed to consist of direct precipitation on a stream network, overland flow to the stream channels, and interflow through shallow subsurface deposits that lie above the water table. Surface runoff occurs in greatest proportion during and immediately following precipitation events but can persist through much of a streamflow hydrograph. Streamflow peaks are identified as surface runoff and are calculated as the difference between the total streamflow and baseflow (Wahl and Wahl 1988; Barlow et al. 2014). The baseflow (or groundwater discharge) component of streamflow supplies flow to streams and is assumed to be continuous in certain conditions and enters the stream channel through delayed pathways within the hydrologic system (Meyboom 1961; Fetter 1994; Sloto and Crouse 1996; Sophocleous 2002; Brodie et al. 2007). Baseflow is calculated as the minimum volume of streamflow over a given time period (n) (Barlow et al. 2014).

Four quantitative hydrograph-separation methods were used in this study, the streamflow partitioning (PART) method (Rutledge 1993, 1998), the HYSEP Fixed and HYSEP Local
Minimum methods developed by Pettyjohn and Henning (1979) and further discussed by Sloto and Crouse (1996), and the Base Flow Index (BFI) Standard method (Wahl and Wahl 1988, 1995). Each method uses a time series of daily mean streamflow measured at a streamgage. Each method is described in detail in the original documentation reports or papers and all methods are summarized in Barlow et al. (2014). Because baseflow cannot be directly observed or quantified and many of the assumptions are untested, it is unknown which method produces the most accurate results (Halford and Mayer 2000) The results of all methods were compared to assess their general accuracy and reliability, as recommended by Mau and Winter (1996), Sloto and Crouse (1996), Neff et al. (2005), and Eckhardt (2008). Kendall's Tau trend analyses were used to determine statistically significant $(\alpha=0.05)$ changes in baseflow over time.

Each of the hydrograph-separation methods is based on a number of simplifying assumptions that limit their applicability (Halford and Mayer 2000). Barlow et al. (2014, pp. 3-5) describes these assumptions and limitations and provides guidance on the appropriateness of their use. All hydrograph-separation methods assume that streamflow originates from two sources: surface runoff within the basin and groundwater discharge from a single aquifer. The methods apply to basins dominated by diffuse, uniform aerial recharge that is discharged continuously to the receiving stream network (Rutledge 1998, 2007; Healy 2010; Barlow et al. 2014). It is further assumed that groundwater and surfacewater divides are coincident, and that there is no loss of groundwater to the underlying regional flow system or to anthropogenic withdrawals (Rutledge 1998, 2007; Healy 2010). Rutledge (1998 and 2000) suggests that the methods be applied to basins having drainage areas ranging from approximately $2.6 \mathrm{~km}^{2}\left(1 \mathrm{mi}^{2}\right)$ to $1,300 \mathrm{~km}^{2}\left(500 \mathrm{mi}^{2}\right)$. Rutledge (2000) also notes that basins of extremely low relief (approximately less than $1 \%$ ) increase the duration of surface runoff, which can impact calculations made by the hydrographseparation methods. As noted by many authors and summarized in Barlow et al. (2014), a number of hydrologic processes and human activities that affect the flow and storage of water within a basin can obscure the surface-runoff and baseflow contributions to a streamflow hydrograph, including snowmelt runoff, drainage from lakes and wetland areas, and streamflow regulation such as occurs at reservoirs, by streamflow diversions, or by wastewater return flows. Because the algorithms that are used by the hydrographseparation methods cannot differentiate among the various causes of hydrograph fluctuations, they may incorrectly identify snowmelt, reservoir releases, and other sources of water to a stream as groundwater discharge. An example hydrograph of daily estimated baseflow using the hydrograph-separation methods for a 2-month period for the Big Sunflower River streamgage at Sunflower, Miss. (USGS station No. 
0728850) is shown in Fig. 3. For the 2-month period, the BFI Standard and PART methods gave the lowest and highest estimated rates of baseflow, respectively, which is consistent with the overall findings of the analysis described in the following. All methods calculate a BFI, or ratio of baseflow to total streamflow, for direct comparison. BFI values can be calculated on daily, monthly, or annual time steps according to the needs of the user.

The Mississippi Delta is instrumented with a spatially distributed network of 11 colocated observation wells and streamgages operated by the US Geological Survey (USGS) in cooperation with the US Army Corps of Engineers (USACE). The network provides continuous data and allows for direct comparison of streamflow with groundwater-level elevations; however, continuous groundwater-level elevation data collection did not begin at the sites until 2014. The groundwater records are not sufficient in length for comparison at this time but are anticipated to be valuable in future scientific studies. Data for this study included daily mean streamflows collected by the USGS and USACE for five of the colocated streamgages (Fig. 4). The five streamgages were selected based on the availability of daily mean streamflow data, period of record, and spatial distribution across the Mississippi Delta (Table 1). Hydrologic data collected by the USGS are publicly available from the USGS National Water Information System (NWIS) web interface (US Geological Survey 2018).

Two of the five selected streamgages had missing daily mean streamflow records. Missing daily mean streamflow records were estimated for the sites using the USGS Streamflow Record Extension Facilitator (SREF; Granato 2009), which uses the Maintenance of Variance-Extension type 1 (MOVE.1) equation in combination with index stations

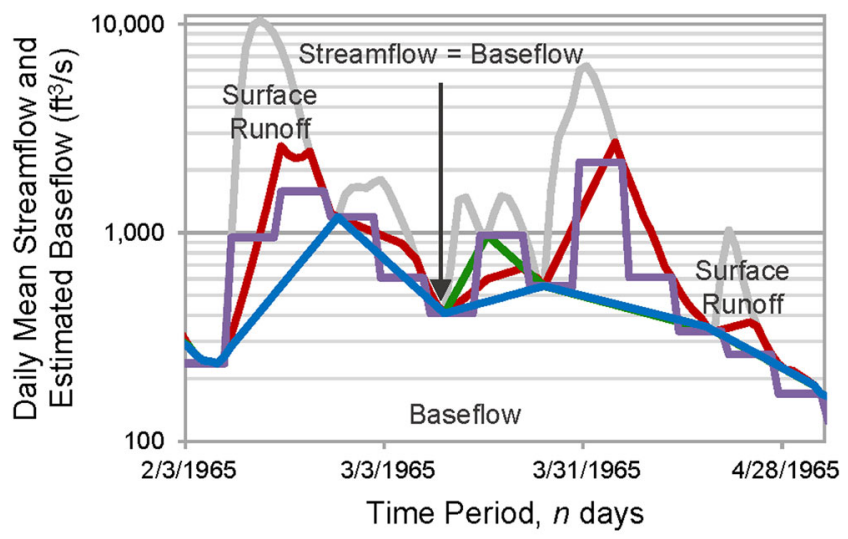

\section{EXPLANATION}

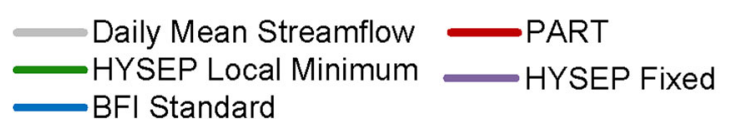

Fig. 3 Example hydrographs showing hydrograph separation by method in cubic feet per second $\left(\mathrm{ft}^{3} / \mathrm{s}\right), 1 \mathrm{ft}^{3} / \mathrm{s}=0.03 \mathrm{~m}^{3} / \mathrm{s}$. The area under each colored line represents the volume of baseflow estimated at a given time

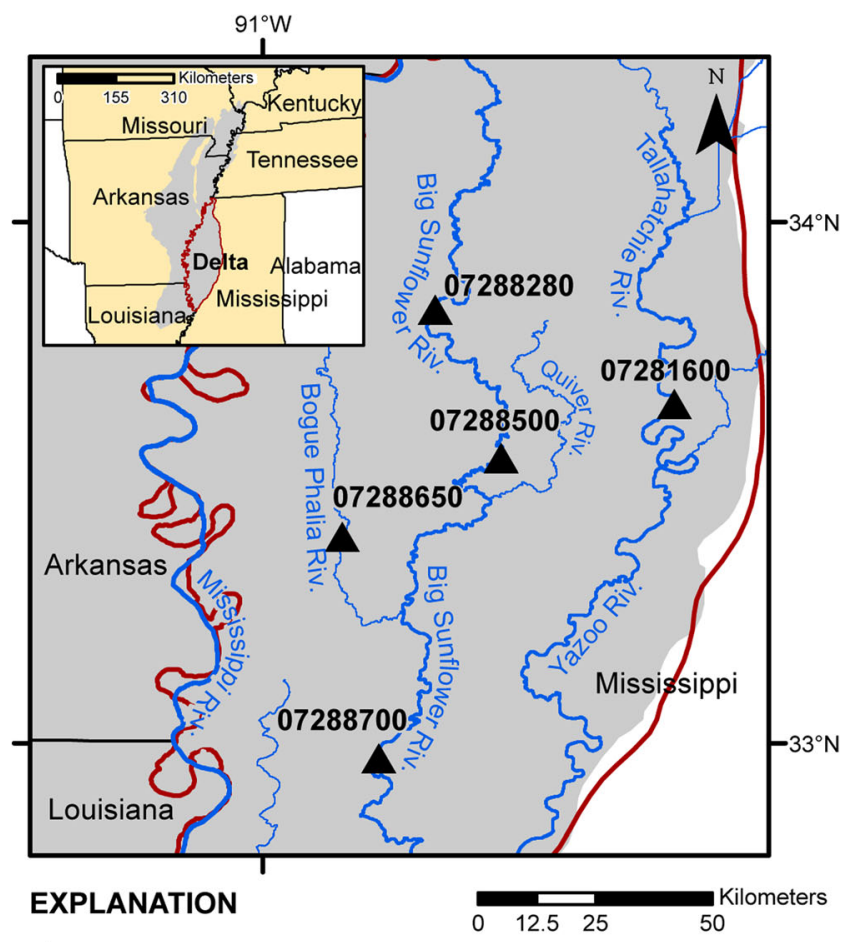

USGS streamgage study sites

$\square$ Study Area

Mississippi River Valley alluvial aquifer

North American Datum of 1983 Base modified from U.S. Geological Survey digital data, 1:2,000,000 Albers Equal Area Projection

Fig. 4 Map of selected sites from the spatially distributed network of colocated streamgage and groundwater well locations within the Mississippi Delta by USGS

(Hirsch 1982; Granato 2009; Curran 2012). The USGS Get National Water Information System Streamflow (GNWISQ) software was used to retrieve available daily mean streamflow data from NWIS and format it for use in SREF (Granato 2009). SREF was used to estimate missing daily mean streamflow values for the Bogue Phalia River streamgage near Leland, MS (USGS station No. 07288650) and the Big Sunflower River streamgage near Anguilla, MS (USGS station No. 07288700 ; Fig. 5). A total of 881 of 19,632 daily mean streamflow values (4.5\%) were estimated for the Bogue Phalia River streamgage using the Big Sunflower River streamgage near Sunflower, MS (USGS station No. 07288500) as an index station. Concurrent daily mean streamflows between the Bogue Phalia River streamgage and the Big Sunflower River streamgage near Sunflower, MS had an $R^{2}$ of 0.847 (Fig. 5a). A total of 2,090 of 2,662 daily mean streamflows (78.5\%) were estimated for the Big Sunflower River streamgage near Anguilla, MS using two index stations: The Big Sunflower River streamgage near Sunflower, MS $\left(R^{2}=0.890\right.$; Fig. 5 b) and the Big Sunflower River streamgage near Merigold, MS (USGS station No. 07288280; $R^{2}=0.832 ;$ Fig. 5c). Streamflow record extension was not used to extend records prior to the initial streamflow 
Table 1 Site information for the five selected USGS streamgage locations used in this study

\begin{tabular}{|c|c|c|c|c|c|}
\hline USGS station No. & $\begin{array}{l}\text { Colocated groundwater well } \\
\text { (USGS station No.) }\end{array}$ & River name & Location & Period of record & $\begin{array}{l}\text { Drainage area } \\
\left(\mathrm{km}^{2}\right)\end{array}$ \\
\hline 07281600 & 333904090123801 & Tallahatchie & Money, MS & $10 / 01 / 1995-12 / 31 / 2017$ & 13,522 \\
\hline 07288280 & 334956090402201 & Big Sunflower & Merigold, MS & $10 / 01 / 1992-12 / 31 / 2017$ & 1,432 \\
\hline 07288500 & 333251090323801 & Big Sunflower & Sunflower, MS & $10 / 01 / 1935-12 / 31 / 2017$ & 1,987 \\
\hline 07288650 & 332348090505301 & Bogue Phalia & Leland, MS & $01 / 01 / 1964-12 / 31 / 2017$ & 1,254 \\
\hline 07288700 & 325817090464201 & Big Sunflower & Anguilla, MS & 09/18/2009-12/31/2016 & 6,680 \\
\hline
\end{tabular}

collection date because of insufficient index stations and the highly altered environment.

The hydrograph-separation methods used in this analysis are part of the overall functionality of the USGS Groundwater Toolbox (Barlow et al. 2017). Continuous daily mean streamflow data are available from NWIS (US Geological Survey 2018) and the USACE (US Army Corps of Engineers 2018), and missing streamflow estimates were calculated using SREF (Granato 2009) and are available from Killian and Asquith (2019). Daily mean streamflow data and calculated baseflow estimates were analyzed by climatic year (April 1st to March 31st). A partition length of $n=5$ days and a turning point test factor of 0.9 were used for the BFI Standard method for all records analyzed. Data for this hydrographseparation analysis are available from Killian and Asquith (2019). The Groundwater Toolbox also facilitates the calculation of Kendall's Tau measure of rank correlation, which was used to identify trends in the data by estimating the magnitude of monotonic change with time (Kendall 1938, 1975; Wahl and Wahl 1988; Wahl and Tortorelli 1997). Baseflow trends were recognized as statistically significant for each $n$-day low- flow period of analysis when the null hypothesis was rejected at the $95 \%$ confidence (such as $p$ value of 0.05 or less) and if Kendall's Tau was trending to +1 or -1 (Fig. $7 \mathrm{~b}$; Wahl and Tortorelli 1997; Helsel and Hirsch 2002).

\section{Generalization of groundwater-level elevations}

To quantify groundwater-level elevation changes systematically in the study area, available groundwater-level elevation data needed to be normalized for space and time because of the spatial and temporal variability of the observations. The majority of the groundwater-level elevation observations were made in the spring and fall months, but such practice was not uniform throughout the period of record. A grid of the study area was created at a $4.5-\mathrm{km}(\mathrm{km})$ spacing; the grid nodes are not coincident with actual wells. Statistical processing (timeseries regression) of the observational groundwater-level elevation data surrounding each grid node was made to estimate the water levels at specific or strategic points in time to give estimates throughout the grid for year $M$ and again for a year
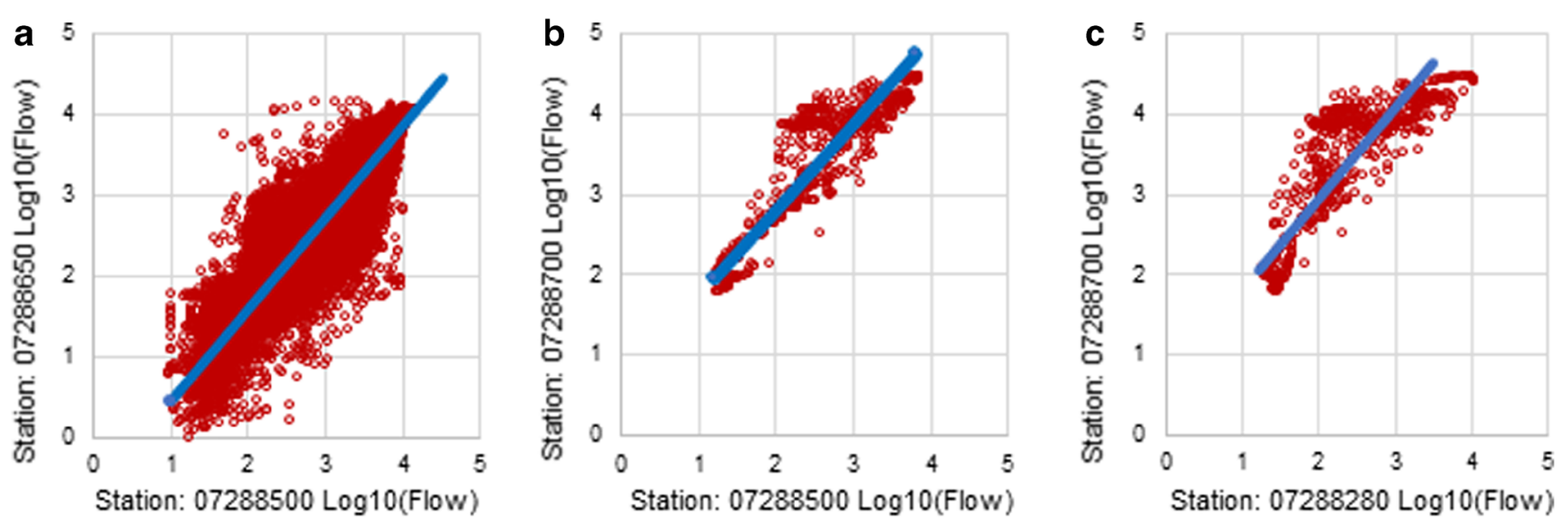

\section{EXPLANATION}

\section{- Streamflow, $\log (\mathrm{x})$ vS. $\log (\mathrm{Y})=$ MOVE.1 trend line}

Fig. 5 Streamflow relation using SREF software computations (Granato 2009) between the Big Sunflower River at Sunflower, MS (USGS station No. 07288500) and a the Bogue Phalia River near Leland, MS (USGS station No. 07288650) and b the Big Sunflower River near Anguilla, MS

(USGS station No. 07288700) and $\mathbf{c}$ between the Big Sunflower River at Merigold, MS (USGS station No. 07288280) and the Big Sunflower River near Anguilla, MS 
$N$. Groundwater-level elevation changes can readily be computed from years $M$ to $N$ in a geographic information system.

For this study, time-series regressions were based on the generalized additive model (GAM) algorithms (Hastie and Tibshirani 1986, 1990; Wood 2017, 2018). These were used to quantify temporal changes in groundwater-level elevation for a given data set in which a data set that included all observations at wells within a set radial distance from a grid node. The GAM is analogous to a linear regression but incorporates additive smoothing functions and can be used to identify trends (Hastie and Tibshirani 1986, 1990; Wood 2017, 2018) and provides a more rigorous framework for trend estimation than available in the lowess and loess functions (Cleveland 1979; Cleveland et al. 1992) in R ( $R$ Development Core Team 2018). Further, temporal data density within the alluvial aquifer was considered insufficient for autoregressive-moving-average type modeling. Extensive testing (not reported here) showed that the GAM had sufficient robustness against outliers in water-level elevations. All available groundwater-level elevation observation data between 1980 and 2016 for the study area in the NWIS database were used, which included more than 3,300 wells and almost 28,000 groundwater-level measurements (US Geological Survey 2018). These data included copious quantities of measurements from local water-resource authorities (YMD 2008) in the region.

Generalized groundwater-level elevation observations were estimated using GAMs, based on the algorithms of Wood (2018), for April 10th of each year for each grid node (4.5 km spacing). April 10th of each year was selected because of the large number of groundwater-level elevation observations made on or immediately before that day as part of other data-collection efforts by local water-resource authorities (YMD 2008). Early April is also prior to the start of irrigation season and is generally a period of approximate maximum water-level recovery in the alluvial aquifer from the previous irrigation season (Snipes et al. 2005). The GAM estimates for each grid node also include the upper and lower 90th-percentile prediction limits.

For each grid node, a GAM was created using an $8-\mathrm{km}$ search radius and included up to 300 nearby wells publicly available from NWIS (Fig. 6; US Geological Survey 2018). A lower limit of 10 groundwater measurements from nearby wells was needed to estimate groundwater-level elevations over time for the specified node. If less than ten measurements were available, no estimate was calculated for the node. If the number of measurements exceeded 100, then an attempt was made to estimate first-order seasonality using paired cosine and sine trigonometric functions for which a cyclical year had 2 times $\pi$ radians (Fig. 6, grid node 298). If the $p$-value for both trigonometric terms was greater than 0.005 , then the GAM was fitted using only the smooth on the date of measurement (Fig. 6, grid node 299). From the gridded estimates, quantification of changes between 1980 and 2016 thus reflect generalized groundwater-level elevation change across the Delta.

An example groundwater-level elevation estimated hydrograph for grid node 0918 based on a GAM using nearby (8-km radius) groundwater-well observations is shown in Fig. 7. For node 0918,122 wells are included with 713 measurements in aggregate. The measurements for the neighboring wells are also shown, and highlights that many observation wells have solitary measurements, especially around 1980 . Figure 7 also shows that some monitoring network wells are nearby as evidence by the twice-yearly measurements. The figure does not highlight the difference in well construction nor is such information used in the statistical modeling.

Several representations of the same GAM are shown (Fig. 7). The continuous month over month predictions of the GAM are depicted by the sinusoidal, light blue line for which the troughs and peaks occur around December and May, respectively. Of primary importance to this study are the April 10th predictions for each year. These have been connected to form the darker solid blue line with the corresponding 90thpercentile prediction limits (not confidence limits; see Helsel and Hirsch 2002). The overall curvature (not the parametric seasonality) of the GAM for the time period shown is controlled by the smooth term that uses only the date of the measurement. The smooth within a GAM is a type of crossvalidated regression spline estimated during the construction of the GAM. The figure indicates that generalization of water levels for each year of interest at this grid node is possible. For the remainder of the nodes, generally unsupervised predictions were made using the other and node-specific GAMs. However, substantial review of GAM results for about 100 grid nodes scattered throughout the study area was done, and the authors conclude that this statistical approach for normalizing for space and time is reliable for the data available for the alluvial aquifer.

\section{Results}

\section{Hydrograph separation and trend analyses}

The degree of groundwater contribution to streamflow, indicated by the average annual base flow index (BFI), varied temporally and spatially among the five study sites. Baseflow contribution to streamflow in the Tallahatchie River at Money, MS (USGS station No. 07281600, Fig. 8a graph A; Table 2) was moderate to high (average annual $\mathrm{BFI}=0.805)$ and varied seasonally. Groundwater contribution to streamflow in the Big Sunflower River at Merigold, MS (USGS station No. 07288280, Fig. 8a, graph B; Table 2), the most upstream study site, was moderate to low (average annual $\mathrm{BFI}=0.366$ ), and the degree of BFI contribution varied 


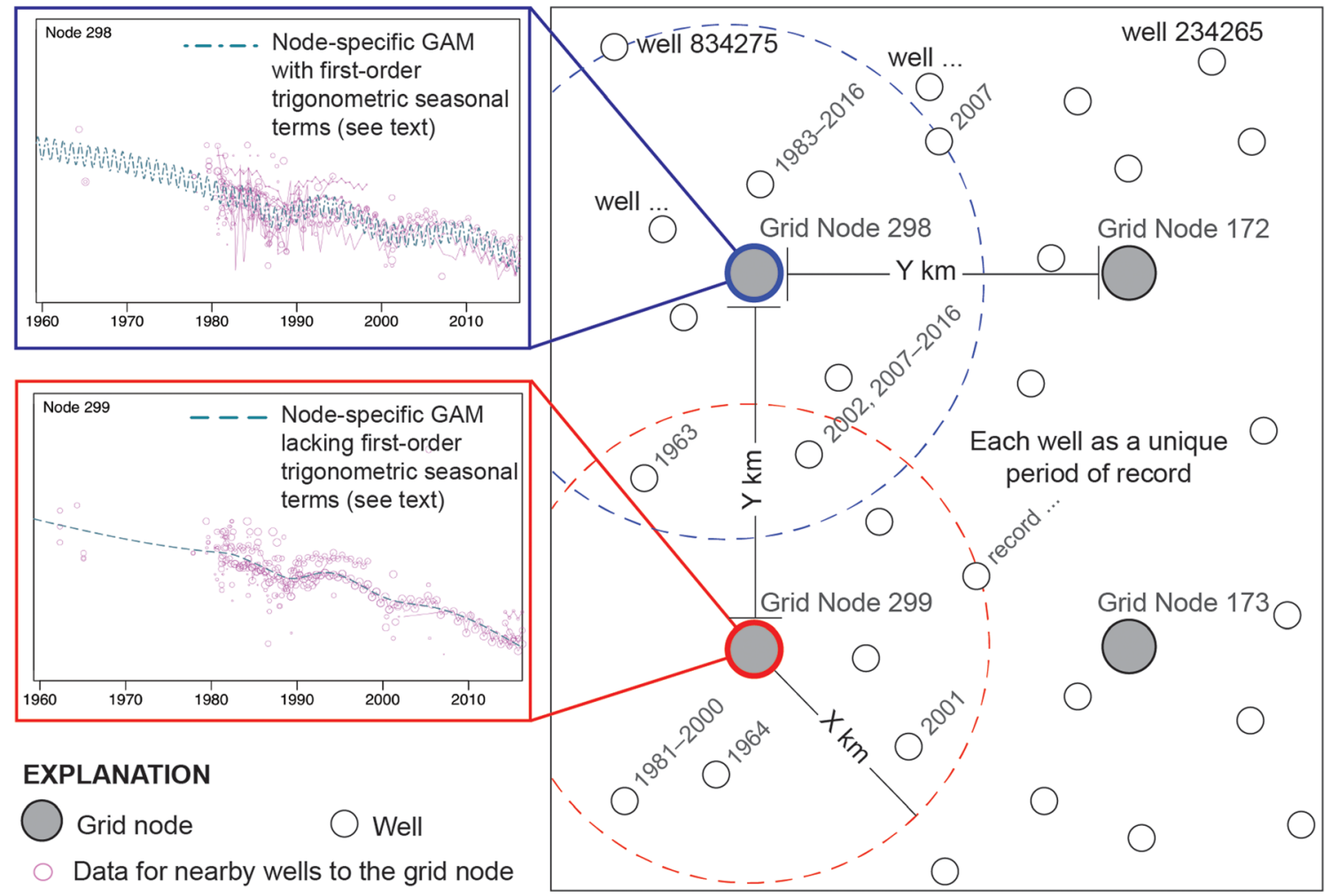

Fig. 6 Diagram of two GAM nodes with associated hydrographs of groundwater-level elevation observations from wells within the search radius. Dates indicate available records from NWIS (US Geological Survey 2018) at each well identified

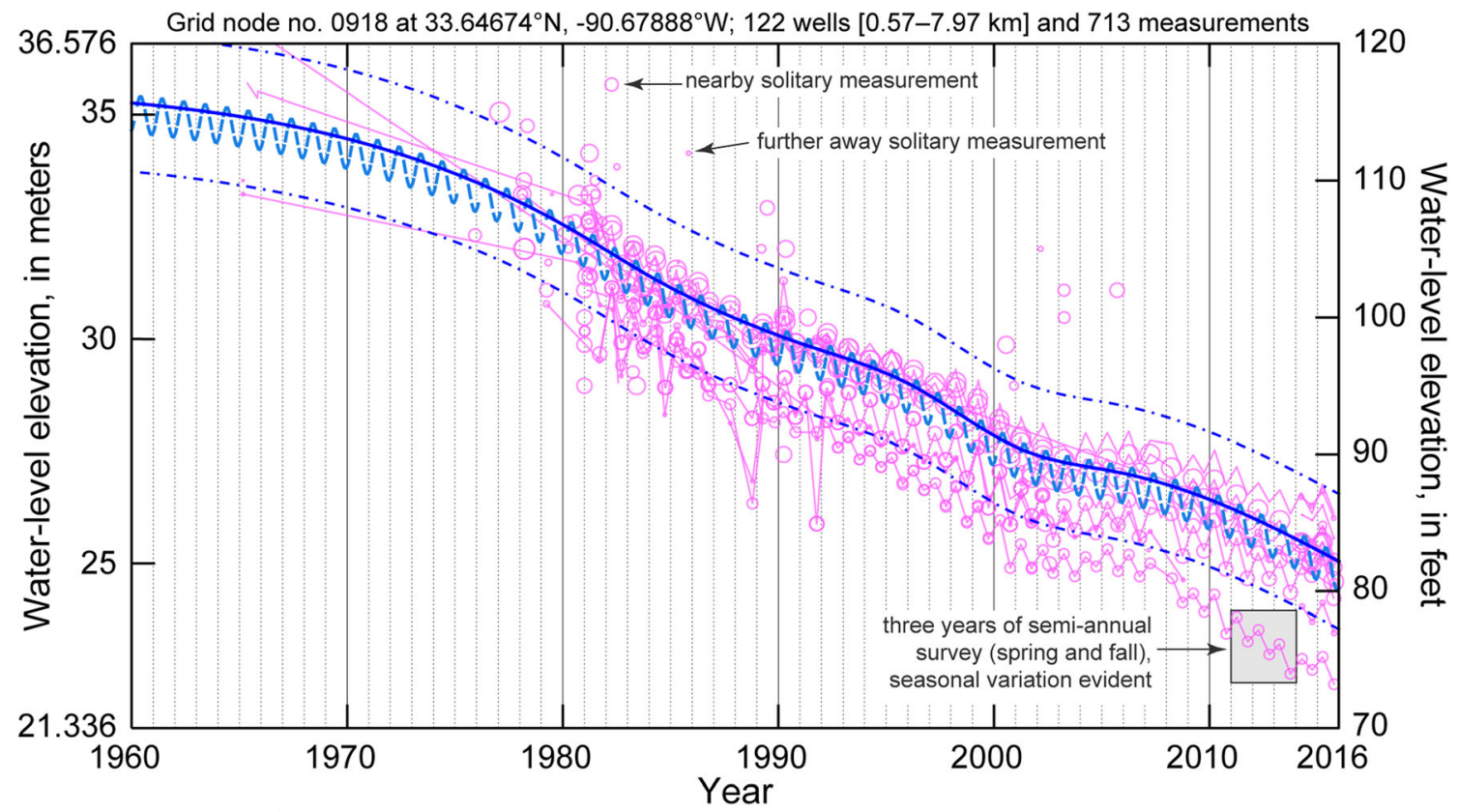

\section{EXPLANATION}

- - - Generalized additive model (GAM; Wood, 2018) using cubic-regression spline smooth on time (measurement dates) and $\sin \left(2 \pi d_{j}\right)+\cos \left(2 \pi d_{i}\right)$ for $d_{j}$ as day-fraction-of-year and model weights inverse to distance from grid node

-... GAM-0410, GAM predictions for April 10th ("-0410") of each year with lower and upper 90th-percentile prediction limits based on residual error (scale) and individual standard errors of estimate on each April 10th.

- Water-level measurements along with a connecting line betweeen successive measurements; symbol size increases as distance between the well and grid node decreases.

Fig. 7 Example hydrograph of groundwater-level elevation for grid node 0918 showing measurements from radially-neighboring wells with fitted generalized additive model 


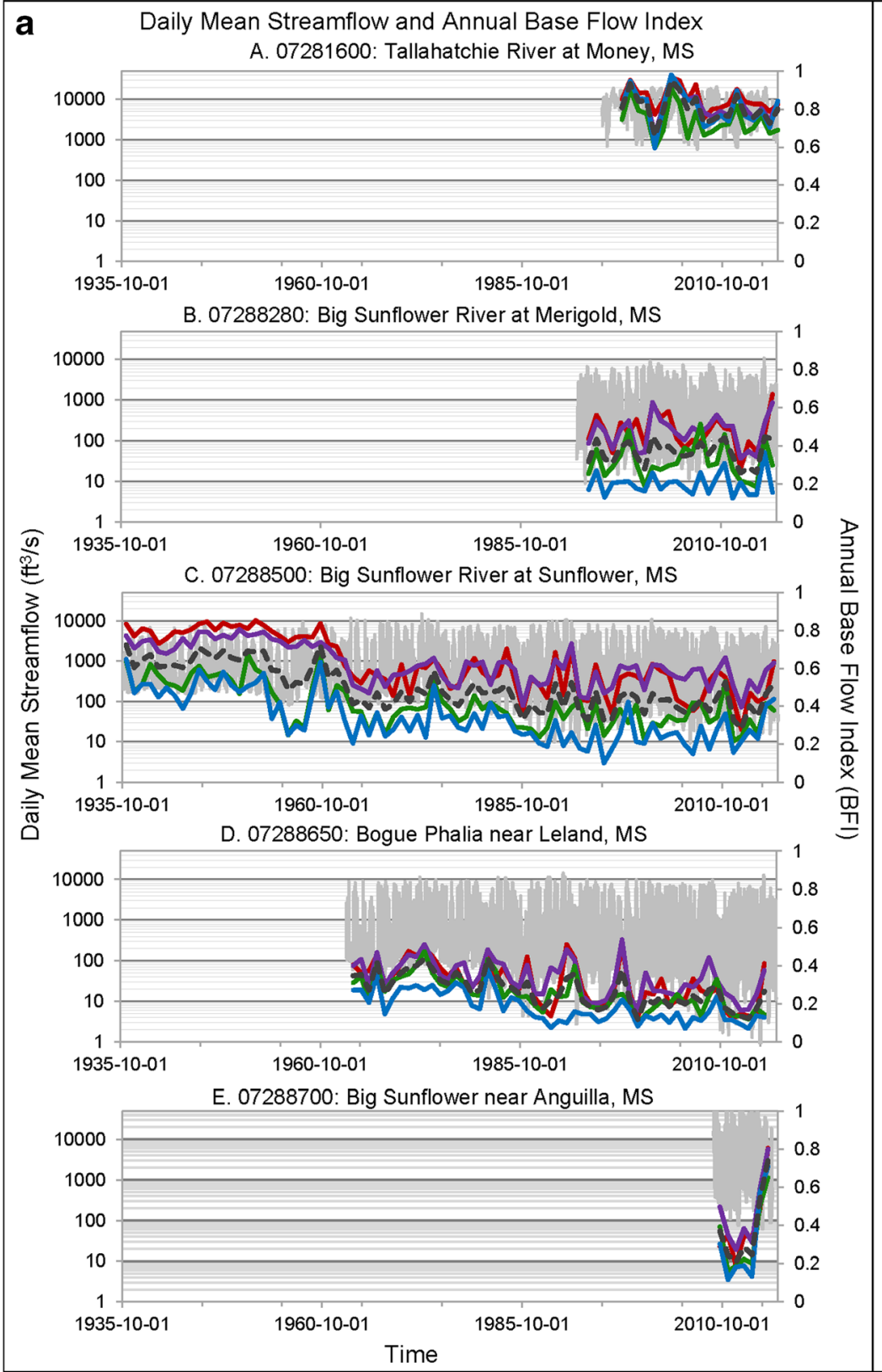

EXPLANATION
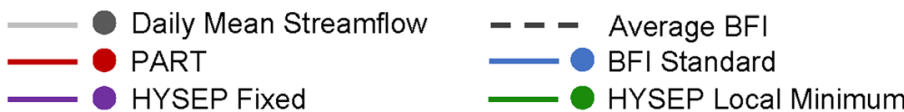

b Statistical Trend Analyses

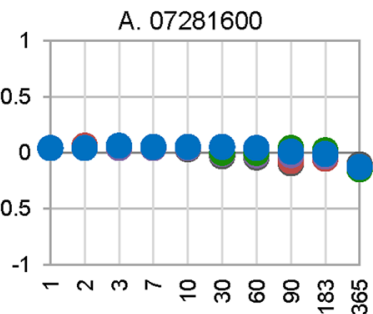

B. 07288280

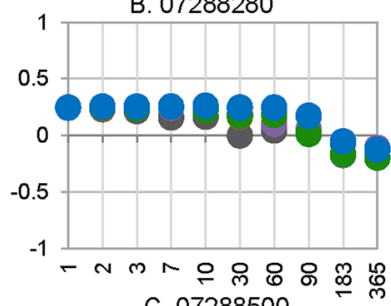

C. 07288500

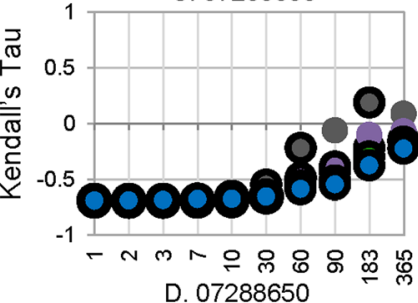

D. 07288650

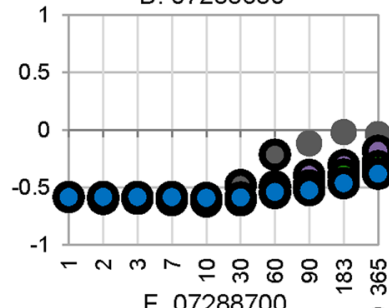

E. 07288700

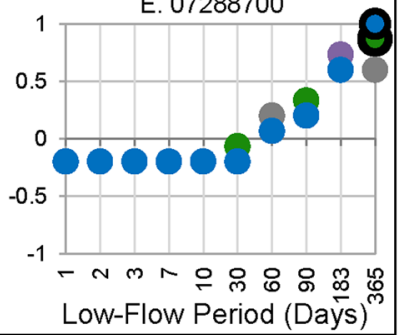

O Statistically Significant

( $p$-value $\leq 0.05$ )

Fig. 8 a Daily mean streamflow $\left(\mathrm{ft}^{3} / \mathrm{s}\right.$ ) and annual mean baseflow time series by streamgage, $1 \mathrm{ft}^{3} / \mathrm{s}=0.03 \mathrm{~m}^{3} / \mathrm{s}$. b Results of the Kendall's Tau trend analyses for baseflow results by streamgage

between high- and low-flow events. Baseflow contributions to streamflow decreased over time (average annual BFI $=0.563$ for 1936-1979 and average annual BFI $=0.418$ for 1980 2016) in the Big Sunflower River at Sunflower, MS (USGS station No. 07288500, Fig. 8a graph C; Table 2). The decrease in BFI and the increasing variability between high- and lowflow events after the 1980s is contemporaneous with increased groundwater withdrawals for irrigation (Fig. 3).
Baseflow contributions to streamflow decrease over time in the Bogue Phalia River (USGS station No. 07288650, Fig. 8a, graph D; Table 2), which corresponds to increases in groundwater withdrawals from the alluvial aquifer (Fig. 3). Hydrograph separation results for the Big Sunflower River near Anguilla, MS (USGS station No. 07288700, Fig. 8a, graph E; Table 2), the most downstream site on the Big Sunflower River, varied but there was a slight increase in 
Table 2 Arithmetic mean annual baseflow index (BFI) calculated from all hydrograph-separation methods for each site, including averages before and after 1980 when applicable

\begin{tabular}{lllll}
\hline USGS station No. & Period of record & Mean annual BFI & $\begin{array}{l}\text { Mean annual BFI } \\
1936-1979\end{array}$ & $\begin{array}{l}\text { Mean annual BFI } \\
1980-2016\end{array}$ \\
\hline 07281600 & $10 / 01 / 1995-12 / 31 / 2017$ & 0.805 & - & - \\
07288280 & $10 / 01 / 1992-12 / 31 / 2017$ & 0.366 & - & - \\
07288500 & $10 / 01 / 1935-12 / 31 / 2017$ & 0.497 & 0.563 & 0.418 \\
07288650 & $01 / 01 / 1964-12 / 31 / 2017$ & 0.270 & 0.345 & 0.238 \\
07288700 & $09 / 18 / 2009-12 / 31 / 2016$ & 0.376 & - & - \\
\hline
\end{tabular}

baseflow contribution over time; however, the period of record for data at this site is short-less than 10 years in length.

Statistically significant declines in baseflow occurred at the Big Sunflower River at Sunflower and Bogue Phalia River sites for most hydrograph-separation methods over most $n$-day periods of analysis. For example, Kendall's Tau values for the 1-day through 30-day analysis periods for the Big Sunflower River at Sunflower were approximately -0.65 (Fig. 8b, graph C); however, the trends became less significant (trended to 0 ) for the 60 to 365 -day analysis periods. There were no statistically significant declines in baseflow in the Big Sunflower River at Merigold and Tallahatchie River sites. The Big Sunflower River streamgage near Anguilla showed an increase in baseflow contribution to streamflow over longer analysis periods (60-365 days) with statistically significant changes for the 365-day time period and no statistically significant change in baseflow over shorter periods (1-30 days). The streamflow record for the Big Sunflower River near Anguilla is for the shortest period of time (2009-2016) and may be insufficient for a trend analysis, so results for this site should be taken with caution.

\section{Generalized groundwater-level elevation change}

A well-defined region of persistent groundwater-level elevation declines is located near the middle of the study area (Fig. 9). The estimated groundwater-level decline based on the difference between April 10, 1980 and April 10, 2016 ranges from approximately zero to more than $12 \mathrm{~m}$. The area of largest decline $(\sim 12 \mathrm{~m})$ is located along the middle reaches of the Big Sunflower River. Groundwater-level elevations have been generally stable on both the eastern and western margins of the study area. This observation is consistent with the persistent flow within the Tallahatchie River that flows near the Bluff Hills and Mississippi River, which may act as areas of recharge for the study area (Arthur 2001; Barlow and Clark 2011). The flow persistency is associated with the substantial surface-water input into the study area from upstream or the headwaters of the rivers. The southern fifth of the study area also shows that groundwater-level elevations have been relatively stable.

\section{Discussion}

Ranges in estimates from the individual hydrographseparation methods at each study site were consistent with findings from previous baseflow separation studies by Neff et al. (2005) and Eckhardt (2008). PART and HYSEP Fixed methods tend to estimate higher baseflow than the HYSEP Local Minimum and BFI Standard methods. Results should be interpreted with caution because the Mississippi Delta is heavily influenced by anthropogenic factors including streamflow-control structures and alterations in landscape to accommodate agriculture. Results from the Big Sunflower River streamgage near Anguilla may be uninformative because of the relatively short period of streamflow record. The Tallahatchie River streamgage also exceeds the recommended drainage basin size of $1,300 \mathrm{~km}^{2}$ (500 $\left.\mathrm{mi}^{2}\right)$ for hydrograph separation and is downstream of streamflow-control structures (Rutledge 1998, 2000; Barlow et al. 2014). The colocated groundwater-observation wells will prove useful for studies such as this in the future as additional data are collected.

The degree of changes in groundwater-level elevation corresponded to changes of baseflow contribution to streamflow both spatially and temporally at the five study sites. Baseflow results for the Big Sunflower River at Merigold and Tallahatchie River streamgages showed no statistically significant change $(\alpha=0.05)$, which is consistent with the relatively small decline in nearby groundwaterlevel elevations ( -2 to $-4 \mathrm{~m}$ [m], Fig. 9). Statistically significant changes in baseflow were observed at the Big Sunflower River streamgage at Sunflower, which showed substantial declines in the nearby generalized groundwaterlevel elevation estimates $(-8$ to $-12 \mathrm{~m})$. An increase in baseflow contribution over time has occurred at the Big Sunflower River streamgage near Anguilla, which is consistent with increases in the nearby groundwater-level elevation (>0 m) as shown in YMD (2008) and Clark et al. 
Fig. 9 Estimated groundwater level elevation change measured as the difference between April 10, 1980 and April 10, 2016 using the generalized additive (statistical) model for each grid node as described in the text
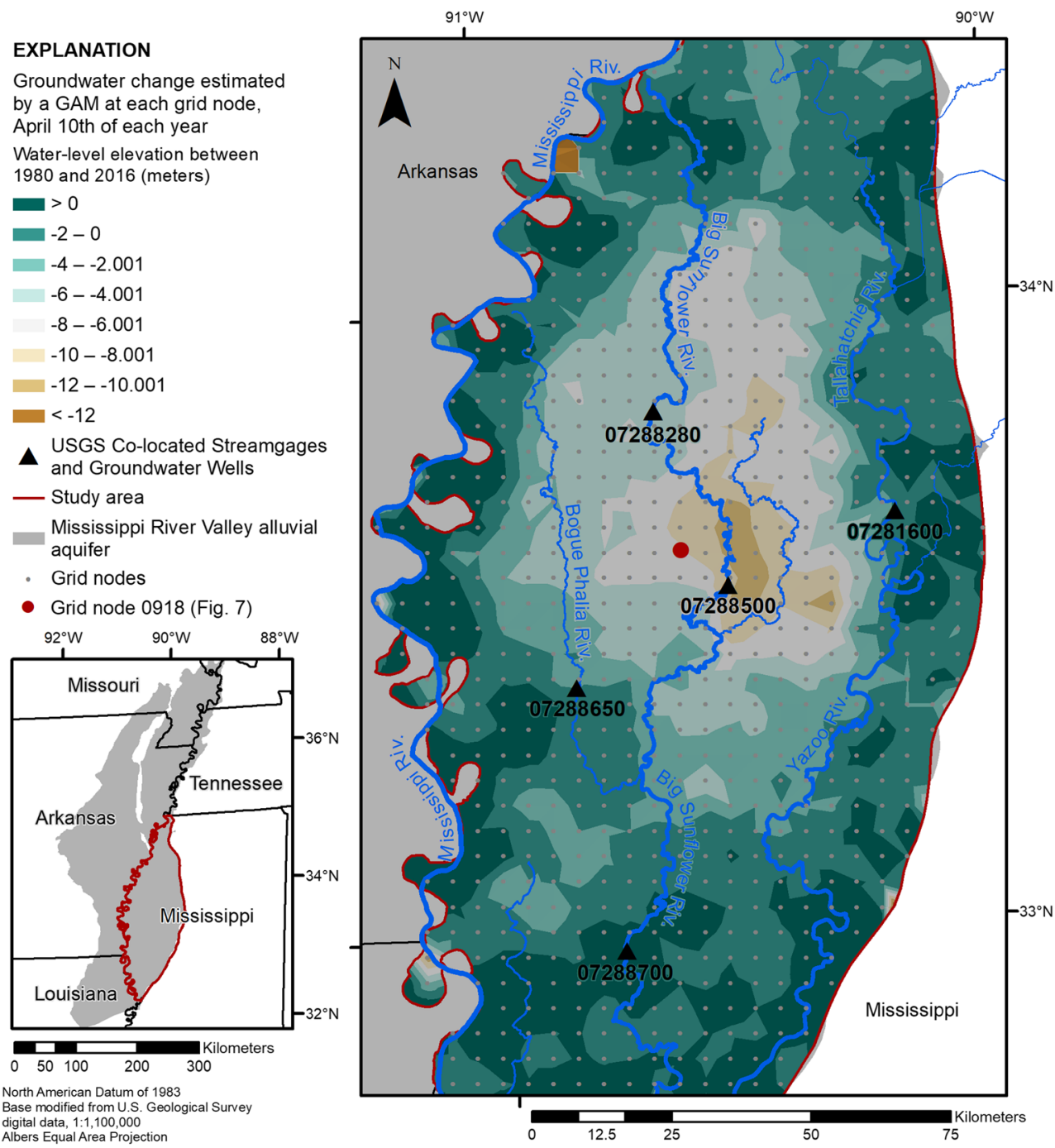

\section{Conclusions}

This study utilized existing groundwater-level elevation and streamflow datasets to quantify changes in baseflow contribution to streamflow at five sites in the Mississippi Delta to define groundwater-level elevation changes over a 26-year time period across the study area. Areas with little or no statistically significant $(\alpha=0.05)$ changes in streamflow and baseflow were observed in areas with little relative change in groundwater-level elevation. Baseflow characterization techniques and analysis of groundwater-level elevation data suggest that decreases in baseflow are a result of groundwater-level elevation declines within in the alluvial aquifer that underlies the Mississippi Delta. Groundwater-level elevation declines within the alluvial aquifer are contemporaneous with increases in groundwater withdrawals from the alluvial aquifer. This research demonstrates that baseflow contributions to streamflow calculated from streamflow data may be used as a proxy for changes in groundwater- 
level elevation over time in alluvial settings. To further evaluate the approach, streamflow should be analyzed on seasonal or decadal scales to identify if observed trends are maintained.

Funding information This research was funded as part of the United States Geological Survey Mississippi Alluvial Plain regional wateravailability study (https://www2.usgs.gov/water/lowermississippigulf/ map/) in cooperation with the Mississippi State University Department of Geosciences. Any use of trade, firm, or product names is for descriptive purposes only and does not imply endorsement by the US Government.

Open Access This article is distributed under the terms of the Creative Commons Attribution 4.0 International License (http:// creativecommons.org/licenses/by/4.0/), which permits unrestricted use, distribution, and reproduction in any medium, provided you give appropriate credit to the original author(s) and the source, provide a link to the Creative Commons license, and indicate if changes were made.

\section{References}

Abo RK, Merkel BJ (2015) Investigation of the potential surfacegroundwater relationship using automated base-flow separation techniques and recession curve analysis in $\mathrm{Al}$ Zerba region of Aleppo, Syria. Arab J Geosci 8:10543-10563. https://doi.org/10. 1007/s12517-015-1965-6

Ackerman DJ (1996) Hydrology of the Mississippi River Alluvial Aquifer, south-central United States. US Geol Surv Prof Pap 1416-D

Alley WM, Reilly TE, Franke OL (1999) Sustainability of ground-water resources. US Geol Surv Circ 1186

Anibas C, Buis K, Verhoeven R, Meire P, Batelaan O (2011) A simple thermal mapping method for seasonal spatial patterns of groundwater-surface water interaction. J Hydrol 39(1-2):93-104. https://doi.org/10.1016/j.khydrol.2010.11.036

Arthur JK (2001) Hydrology, model description, and flow analysis of the Mississippi River alluvial aquifer in northwestern Mississippi. US Geol Surv Water Resour Invest Rep 01-4035

Barlow JRB, Clark BR (2011) Simulation of water-use conservation scenarios for the Mississippi Delta using an existing regional groundwater flow model. US Geol Surv Sci Invest Rep 2011-5019

Barlow PM, Leake SA (2012) Streamflow depletion by wells: understanding and managing the effects of groundwater pumping on streamflow. US Geol Surv Circ 1376

Barlow PM, Cunningham WL, Zhai T, Gray M (2014) US Geological Survey groundwater toolbox, a graphical and mapping interface for analysis of hydrologic data (version 1.0): user guide for estimation of base flow, runoff, and groundwater recharge from streamflow data. US Geol Surv Techniques and Methods, book 3, chapter B10. US Geological Survey, Reston, VA. https://doi.org/10.3133/tm.3B10

Barlow PM, Cunningham WL et al (2017) US Geological Survey groundwater toolbox version 1.3.1, a graphical and mapping interface for analysis of hydrologic data. https://doi.org/10.3133/tm3B10

Barthel R, Banzhaf S (2015) Groundwater and surface water interaction at the regional-scale: a review with focus on regional integrated models. Water Resour Manag 30:1-32. https://doi.org/10.1007/ s11269-015-1163-z

Boswell EH, Cushing EM, Hosman RL (1968) Quaternary aquifers in the Mississippi embayment. US Geol Surv Prof Pap 448-E

Brodie R, Sundaram B, Tottenham R, Hostetler S, Ransley T (2007) An overview of tools for assessing groundwater-surface water connectivity. Bureau of Rural Sciences, Canberra, Australia
Burt OR, Baker M, Helmers GA (2002) Statistical estimation of streamflow depletion from irrigation wells. Water Resour Res 38(12):1296. https://doi.org/10.1029/2001WR000961

Clark BR, Hart RM (2009) The Mississippi embayment regional aquifer study (MERAS): documentation of a groundwater-flow model constructed to asses water availability in the Mississippi embayment. US Geol Surv Sci Invest Rep 2009-5172

Clark BR, Hart RM, Gurdak JJ (2011) Groundwater availability of the Mississippi embayment. US Geol Surv Prof Pap 1785

Cleveland WS (1979) Robust locally weighted regression and smoothing scatterplots. J Am Stat Assoc 74(368):829-836

Cleveland WS, Grosse E, Shyu WM (1992) Local regression models. In: Hastie TJ (ed) Statistical models. Taylor and Francis, London

Curran JH (2012) Streamflow record extension for selected streams in the Susitna River basin, Alaska. US Geol Surv Sci Invest Rep 20125210

Cushing EM, Boswell EH, Hosman RL (1964) General geology of the Mississippi embayment. US Geol Surv Prof Pap 448-B

Eckhardt K (2008) A comparison of baseflow indices, which were calculated with seven different baseflow separation methods. J Hydrol 352:1-2. https://doi.org/10.1016/j.jhydrol.2008.01.005

Essaid HI, Caldwell RR (2017) Evaluating the impact of irrigation on surface water-groundwater interaction and stream temperature in an agricultural watershed. Sci Total Environ 599-600:581-596. https:// doi.org/10.1016/j.scitotenv2017.04.205

Fetter CW (1994) Applied hydrogeology. Prentice-Hall, Upper Saddle River

Forstall RL (1995) Mississippi Population of Counties by Decennial Census: 1900 to 1990. US Bureau of the Census, Washington, DC. https://www.census.gov/population. Accessed April 2019

Granato GE (2009) Computer programs for obtaining and analyzing daily mean streamflow data from the US Geological Survey National Water Information System web site. US Geol Surv Open-File Rep 2008-1362

Halford KJ, Mayer GC (2000) Problems associated with estimating ground water discharge and recharge from stream-discharge records. Ground Water 38(3):331-342

Hastie TJ, Tibshirani RJ (1986) Generalized additive models. Stat Sci 1(3):297-318

Hastie TJ, Tibshirani RJ (1990) Generalized additive models. CRC, Boca Raton, FL

Healy RW (2010) Estimating groundwater recharge. Cambridge University Press, Cambridge, UK, 245 pp

Helsel DR and Hirsch RM (2002) Statistical methods in water resources, In: Techniques of water-resource investigations of the United States Geological Survey, Book 4, Hydrologic Analysis and Interpretation. US Geological Survey, Reston, VA, 522 pp

Hirsch RM (1982) A comparison of four streamflow record extension techniques. Water Resour Res 18(4):1081-1088

Hutson SS, Barber NL, Kenny JF, Linsey KS, Lumia DS, Maupin MA (2004) Estimated use of water in the United States in 2000. US Geol Surv Circ 1268

Juracek KE (2015) Streamflow characteristics and trends at selected streamgages in southwest and south-Central Kansas. US Geol Surv Sci Invest Rep 2015-5167. https://doi.org/10.3133/ sir20155167

Juracek KE, Eng K (2017) Streamflow alteration at selected sites in Kansas. US Geol Surv Sci Invest Rep 2017-5046. https://doi.org/ $10.3133 /$ sir20175046

Kendall MG (1938) A new measure of rank correlation. Biometrika Trust 30(1/2):81-93

Kendall MG (1975) Rank correlation methods, 4th edn. Griffin, London

Killian CD, Asquith WH (2019) Estimated and measured streamflow and groundwater-level data in the Mississippi Delta. US Geol Surv data release. https://doi.org/10.5066/F77D2TD0 
Kress WH, Barlow JRB, Hunt R, Pindilli E (2018) Coupling groundwater flow modeling with hydrologic monitoring to assess water availability in the Mississippi alluvial plain. Mississippi Water Resources Conference, Jackson, MS, April 2018

Mau DP, Winter TC (1996) Estimating ground-water recharge from streamflow hydrographs for a small mountain watershed in a temperature humid climate, New Hampshire, USA. Ground Water 35(2):291-304

Maupin MA, Barber NL (2005) Estimated withdrawals from principal aquifers in the United States. US Geol Surv Circ 1279

McCallum AM, Anderson MS, Giambastiana BMS, Kelly BFJ, Acworth RI (2013) River-aquifer interactions in a semi-arid environment stressed by groundwater abstraction. Hydrol Process 27:10721085. https://doi.org/10.1002/hyp.9229

Meyboom P (1961) Estimating ground-water recharge from stream hydrographs. J Geophys Res 66(4):1203-1214

Miller MP, Johnson HM, Suson DD, Wolock DM (2015) A new approach for continuous estimation of baseflow using discrete water quality data: method description and comparison with baseflow estimates from two existing approaches. J Hydrol 552:203-210 https://doi. org/10.1016/j.jhydrol.2014.12.039

Neff BP, Day SM, Piggot AR, Fuller LM (2005) Base flow in the Great Lakes Basin, US Geol Surv Sci Invest Rep 2005-5217

National Oceanic and Atmospheric Administration (NOAA) (2018) Climate at a glance: Divisional Time Series. National Centers for Environmental Information. https://www.ncdc.noaa.gov/cag/. Accessed July 18, 2018

Pennington DA, Stiles M (1994) Use of regression analysis to evaluate water level changes in the Mississippi River Alluvial Aquifer. Yazoo Mississippi Delta Joint Water Management District, Stoneville, MS

Peterson SM, Flynn AT, Vrable J, Ryter DW (2015) Simulation of groundwater flow and analysis of the effects of water-management options in the North Platte natural resources district, Nebraska. US Geol Surv Sci Invest Rep 2015-5093. https://doi.org/10.3133/ $\operatorname{sir} 20155093$

Pettyjohn WA, Henning R (1979) Preliminary estimate of ground-water recharge rates, related streamflow and water quality in Ohio. Ohio State University Project Completion Report no. 552, State of Ohio Water Resources Center, Columbus, $\mathrm{OH}$

R Development Core Team (2018) R: a language and environment for statistical computing, version 3.4.2. R Foundation for Statistical Computing, Vienna. https://www.R-project.org. Accessed April 2019

Reitz M, Sanford WE, Senay GB, Cazenas J (2017) Annual estimates of recharge, quick-flow, and evapotranspiration for the contiguous U.S. using empirical regression equations. J Am Water Resour Assoc 53(4):961-983

Renken RA (1998) Segment 5 Arkansas. In: US Geol Surv Hydrologic Atlas $730-\mathrm{F}$

Rutledge AT (1993) Computer programs for describing the recession of ground-water discharge and for estimating mean ground-water recharge and discharge from streamflow records. US Geol Surv Water Resour Invest Rep 93-4121

Rutledge AT (1998) Computer programs for describing the recession of ground-water discharge and for estimating mean ground-water recharge and discharge from streamflow records: updated. US Geol Surv Water Resour Invest Rep 98-4148

Rutledge AT (2000) Considerations for use of the RORA program to estimate ground-water recharge from streamflow records. US Geol Surv Open-File Rep 2000-156, 44 pp

Rutledge AT (2007) Computer programs for describing the recession of ground-water discharge and for estimating mean ground-water recharge and discharge from streamflow records - update, US Geol Surv Water Resour Invest Rep 98-4148, 43 pp
Sahoo S, Jha MK (2017) Numerical groundwater-flow modeling to evaluate potential effects of pumping and recharge: implications for sustainable groundwater management in the Mahanadi delta region, India. Hydrogeol J 25:2485-2511. https://doi.org/10.1007/s10040017-1610-4

Sloto RA, Crouse MY (1996) HYSEP: a computer program for streamflow hydrograph separation and analysis. US Geol Surv Water Resour Invest Rep 96-4040

Snipes CE, Nichols SP, Poston DH, Walker TW, Evans LP, Robinson HR (2005) Current agricultural practices of the Mississippi Delta. Office of Agricultural Communications Bull 1143, Mississippi State University, Jackson, MS

Sophocleous M (2002) Interactions between groundwater and surface water: the state of the science. Hydrogeol J 10:52-67. https://doi. org/10.1007/s10040-001-0170-8

Spalding CP, Khaleel R (1991) An evaluation of analytical solutions to estimate drawdowns and stream depletions by wells. Water Resour Res 27(4):597-609

Telis PA (1991) Low-flow and flow-duration characteristics of Mississippi streams. US Geol Surv Water Resour Invest Rep 904087

Theis CV (1940) The source of water derived from wells: essential factors controlling the response of an aquifer to development. Civ Eng 10: 277-280

Theis CV (1941) The effects of a well on the flow of a nearby stream. Trans Am Geophys Union 22(3):734-738

US Army Corps of Engineers (2018) RiverGages.com: water levels of rivers and lakes. www.rivergages.mvr.usace.army.mil/ WaterControl. Accessed January 2018

US Bureau of the Census (2017) Annual estimates of the resident population: April 1, 2010 to July 1, 2016. US Bureau of the Census, Population Division. https://www.factfinder.census.gov. Accessed July 2018.

US Geological Survey (2018) National Water Information System—Web interface. https://doi.org/10.5066/F7P55KJN

Verry ES (2003) Ground water and small research basins: an historical perspective. Ground Water 41(7):1005-1007

Wahl KL, Tortorelli RL (1997) Changes in flow in the Beaver-North Canadian River Basin upstream from Canton Lake, Western Oklahoma. US Geol Surv Water Resour Invest Rep 96-4304

Wahl KL, Wahl TL (1988) Effects of regional ground-water level declines on streamflow in the Oklahoma panhandle. In: Proceedings of the symposium on water-use data for water resources management. American Water Resources Association, Middleburg, VA, pp 239249

Wahl KL, Wahl TL (1995) Determining the flow of Comal Springs at New Braunfels, Texas. In: Proceedings of Texas Water '95. American Society of Civil Engineering, San Antonio, TX, pp 77-86

Winter TC (1995) Recent advances in understanding the interaction of groundwater and surface water. Rev Geophys Supplement, pp 985994. https://doi.org/10.1029/95RG00115

Winter TC, Harvey JW, Franke OL, Alley WM (1998) Ground water and surface water a single resource. US Geol Surv Circ 1139

Wood SN (2017) Generalized additive models: an introduction with R, 2nd edn. CRC, Boca Raton

Wood SN (2018) mgcv - Mixed GAM computation vehicle with automatic smoothness estimation. R package version 1.8-23. https:// CRAN.R-project.org/package $=$ mgcv. Accessed January 15, 2018

Yang Z, Zhou Y, Wenninger J, Uhlenbrook S, Wang X, Wan L (2017) Groundwater and surface-water interactions and impacts of human activities in the Hailiutu catchment, Northwest China. Hydrogeol J 25:1341-1355. https://doi.org/10.1007/s10040-017-1541-0

Yazoo Mississippi Delta Joint Water Management District (YMD) (2008) 2008 annual report. https://www.ymd.org/about.htm. Accessed April 2019 